\title{
Respon Pemberian Campuran Kompos Baglog Dengan Pupuk Kandang Sapi dan Pupuk Organik Cair (POC) Limbah Cair Pabrik Kelapa Sawit Terhadap Pertumbuhan dan Produksi Tanaman Kacang Panjang (Vigna sinensis L.)
}

\section{Response To The Mixed Baglog Compost To Cows Manure And Liquid Organic (POC) Liquid Waste Of Palms To The Growth And Production Of Long Bean (Vigna sinensis L.)}

\author{
Muhammad Rio Purnomo'), Elle Lumisar Panggabean'), Siti Mardiana1)*
}

1) Program Studi Agroteknologi, Fakultas Pertanian, Universitas Medan Area, Indonesia

\begin{abstract}
Abstrak
Penelitian ini dilaksanakan di lahan percobaan Universitas Medan Area, Penelitian ini dilakukan dengan menggunakan metode Rancangan Acak Kelompok (RAK) Faktorial yang terdiri dari dua faktor perlakuan, yaitu : 1) Pupuk kompos campuran baglog dengan pupuk kandang sapi (notasi B) dan 2) Pupuk organik limbah cair pabrik kelapa sawit (notasi K). Adapun parameter yang diamati dalam penelitian ini adalah diameter batang (cm), umur berbunga (hari), jumlah polong/tanaman sampel (buah), panjang polong/tanaman sampel (cm), berat polong/tanaman sampel (g) dan produksi/plot (kg). Kesimpulan dari penelitian ini sebagai berikut : 1) Pemberian campuran kompos baglog dengan pupuk kandang sapi berpengaruh tidak nyata terhadap diameter batang, jumlah polong per tanaman sampel, panjang polong per tanaman sampel, berat polong per tanaman sampel dan produksi per plot, tetapi berpengaruh nyata terhadap umur berbunga; 2) Pemberian POC limbah cair kelapa sawit berpengaruh nyata terhaap diameter batang umur 5 MST, umur berbunga, jumlah polong per tanaman sampel, panjang polong per tanaman sampel, berat polong per tanaman sampel dan produksi per plot; dan 3) Kombinasi kedua faktor perlakuan berpengaruh nyata terhadap panjang polong per tanaman sampel dan produksi per plot, tetapi berpengaruh tidak nyata terhadap parameter lainnya.

Kata Kunci: Kompos baglog, pupuk kandang sapi, POC limbah cair kelapa sawit, kacang panjang
\end{abstract}

\begin{abstract}
The research was conducted in farm experiment faculty of agriculture, the University of Medan Area The research was done by using the method of random designs that the group 's group (RAK) are composed of two treatment factors, those are: 1) Mixed of baglog compostwith cows manure (notation B) 2) Organic fertilizer, liquid waste of palm(notation $K$ ) consisting of 4 treatments, are $K o=$ without treatment, K1=liquid waste $50 \mathrm{ml} / \mathrm{l} / \mathrm{plants}$, K2=chemicals $75 \mathrm{ml} / \mathrm{l} /$ plants, $\mathrm{K3}=$ liquid waste $100 \mathrm{ml} / \mathrm{l} /$ plants. Every treatment repeated as much as two times. The parameters in this study is focus on the diameter of steam (cm), flowering age (day), total of pods/plants (fruits), long pods/plants (cm), thick/ plants $(\mathrm{g})$, and production/plot ( $\mathrm{kg}$ ). The conclusion of this study as follows: 1) giving the mixed Baglog compost with cows manure had no real effects to the diameter of steam, total pods per plants, long pods/plants, thick and plants, and productions/plot but it had real effects to flowering age. 2) giving thePOC liquid waste ofpalms had the real effects to the diameter of steam 5 MST ages, flowering age, total pods per plants, long pods per plants, thick per plants, and production. And 3) the combination both of factors had real effects to long pods per plants, and production per plot, but had no real effects to the others parameters.
\end{abstract}

Keywords: Baglog compost, cows manure, POC liquid waste of palms, long bean.

How to Cite: Muhammad, R.P. Elle, L. P. \& Siti, M. (2020). Respon Pemberian Campuran Kompos Baglog Dengan Pupuk Kandang Sapi dan Pupuk Organik Cair (POC) Limbah Cair Pabrik Kelapa Sawit Terhadap Pertumbuhan dan Produksi Tanaman Kacang Panjang (Vigna sinensis L.). (JIPERTA), 2 (1): 33-43 
Muhammad Rio Purnomo, Ellen Lumisar Panggabean \& Siti Mardiana, Respon Pemberian Campuran Kompos Baglog Dengan Pupuk Kandang Sapi dan Pupuk Organik Cair (POC) Limbah Cair Pabrik Kelapa Sawit Terhadap Pertumbuhan dan Produksi Tanaman Kacang Panjang (Vigna sinensis L.)

\section{PENDAHULUAN}

Kacang panjang adalah salah satu jenis sayuran yang sudah sangat populer di kalangan masyarakat Indonesia maupun dunia. Masyarakat dunia menyebutnya dengan nama Yardlong Beans/Cow Peas. Plasma nutfah tanaman kacang panjang berasal dari India dan Cina. Ada juga yang menduga berasal dari kawasan Afrika. Plasma nutfah kacang uci (Vigna umbellata) ditemukan tumbuh liar di daerah Himalaya India, sedangkan plasma nutfah kacang tunggak (Vigna unguculata) merupakan asli dari Afrika. Oleh karena itu, tanaman kacang panjang tipe merambat berasal dari daerah tropis dan Afrika, terutama Abbisinia dan Ethiopia. Kacang panjang merupakan salah satu tanaman sayuran sebagai sumber vitamin dan mineral. Fungsinya sebagai pengatur metabolisme tubuh, meningkatkan kecerdasan dan ketahanan tubuh memperlancar proses pencernaan karena kandungan seratnya yang tinggi.

Kacang panjang merupakan tanaman semusim yang berbentuk perdu. Tanaman ini bersifat memanjat dengan membelit. Daunnya bersusun tiga-tiga helai. Batangnya panjang, liat dan sedikit berbulu. Bunga kacang panjang seperti kupu-kupu. Sementara buahnya bulat panjang dan ramping. Panjangnya ada yang mencapai 10-80 cm. yang disebut polong. Saat muda buahnya berwarna hijau keputih-putihan, setelah tua berwarna putih kekuning-kuningan dan kering. Buah yang masih muda sangat mudah dipatahkan. Akan tetapi setelah tua menjadi liat karena banyak seratnya dan menjadi lemas jika kering (Sunarjono, 2008).

Sayur ini banyak mengandung vitamin A, vitamin B dan vitamin C terutama pada polong yang masih muda. Biji kacang panjang banyak mengandung lemak, protein, dan karbohidrat. Dengan demikian, komoditi ini merupakan sumber protein nabati yang cukup potensial (Haryanto, 2008). Berdasarkan data yang didapatkan dari Badan Pusat Statistik Republik Indonesia, produktivitas kacang panjang terus mengalami penurunan dari tahun 2012 hingga tahun 2015. Tahun 2012 produksi kacang panjang 455,615 ton/ha, tahun 2013 turun menjadi 450,859 ton/ha, tahun 2014 sebanyak 450,727 ton/ha, dan pada tahun 2015 turun menjadi 395,524 ton/ha (Badan Pusat Statistik, 2016).

Produksi tanaman kacang panjang terus mengalami penurunan, salah satunya diakibatkan oleh penggunaan pupuk kimia sebagai sumber unsur hara secara terus menerus yang mengakibatkan rusaknya organisme tanah sehingga tidak terjaganya keseimbangan lingkungan. Jadi, salah satu usaha untuk meningkatkan produksi kacang panjang dapat dilakukan dengan penggunaan pupuk organic (Rahmah dkk., 2019 ; Simajuntak dkk., 2019). Pupuk organik adalah pupuk yang tersusun dari materi mahluk hidup. Keunggulan dari penggunaan pupuk organik yaitu dapat memperbaiki sifat kimia dan fisika tanah, meningkatkan daya serap tanah terhadap air, meningkatkan efektivitas mikroorganisme tanah, sumber makanan bagi tanaman, ramah lingkungan, dan meningkatkan kualitas produksi. Berdasarkan keadaan fisiknya, pupuk organik dibedakan menjadi dua yaitu, pupuk organik padat dan pupuk organik cair. Pupuk organik cair adalah jenis pupuk organik yang bentuknya berupa cairan, sementara itu 
pupuk organik padat adalah jenis pupuk yang bentuknya berupa padatan, seperti pupuk kandang, pupuk hijauan, kompos, dan humus (Pranata, 2010).

Salah satu alternatif pupuk organik padat yang dapat digunakan yaitu pupuk kompos baglog. Media tanam jamur atau baglog jamur adalah substrat tempat tumbuh jamur. Baglog jamur tiram dibuat dari pencampuran serbuk kayu gergaji dengan dedak, kapur dan gips (Susilowati dan Raharjo, 2004). Chazali (2009) menyatakan bahwa komposisi dari baglog jamur terdiri dari $80 \%$ serbuk gergaji, $10 \%$ dedak padi, 1,8\% kapur, $1,8 \%$ gipsum dan $0,4 \%$ TS. Kurniawan (2008), menyatakan bahwa berdasarkan komposisi limbah baglog jamur dengan $80 \%$ serbuk gergaji dan $10 \%$ dedak padi yang ada dalam baglog jamur merupakan bahan baku super karbon (Sahputra dkk., 2019 ; Nubriama dkk., 2019). Setyorini (2005), menyatakan bahwa pupuk organik mengandung unsur hara makro (N, P, K) dan mikro (Ca, Mg, Fe, Mn, Bo, S, Zn dan Co) yang dapat memperbaiki struktur tanah. Pemakaian pupuk organik pada tanah liat akan mengurangi kelengketan sehingga mudah diolah. Sedang pada tanah berpasir dapat meningkatkan daya ikat tanah terhadap air dan udara.

Baglog jamur yang tidak terpakai lagi akan dibuang sehingga menimbulkan limbah. Limbah media tanam jamur tiram adalah bahan yang berasal dari media tanam jamur tiram setelah dipanen. Komposisi limbah tersebut mempunyai kandungan nutrisi seperti P 0,7\%, K 0,3\%, $\mathrm{N}$ total 0,7\% dan C-organik 49,00\% sehingga bermanfaat untuk meningkatkan kesuburan tanah (Sulaiman, 2011). Limbah ini juga dapat dijadikan kompos setelah dicampur dengan kotoran kambing (Rahmah, dkk., 2014). Sedangkan pupuk organik cair yang dapat digunakan adalah pupuk organik cair limbah cair pabrik kelapa sawit. Limbah cair pabrik kelapa sawit yang juga dikenal dengan Palm Oil Mill Effluent (POME) merupakan hasil sampingan dari pengolahan tandan buah segar kelapa sawit menjadi minyak sawit kasar. POME adalah air limbah industri minyak kelapa sawit yang merupakan salah satu limbah agroindustri yang menyebabkan polusi terbesar (Zahara,2014).

Dengan banyaknya industri pabrik kelapa sawit saat ini, sehingga limbah cair pabrik kelapa sawit yang dihasilkan pun semakin meningkat, maka belakangan ini banyak orang yang memanfaatkan limbah cair pabrik kelapa sawit sebagai pupuk organik cair (POC). Menurut Ideriah, et al (2007) menyatakan limbah cair pabrik kelapa sawit (LCPKS) mengandung unsur hara sehingga dapat dimanfaatkan sebagai sumber pupuk organik bagi tanaman tanaman. Unsur hara yang banyak terdapat dalam limbah cair pabrik kelapa sawit (LCPKS) adalah N (450-590 mg/L), P (92-104 mg/L), K (1,246$1,262 \mathrm{mg} / \mathrm{L})$ dan $\mathrm{Mg}(249-271 \mathrm{mg} / \mathrm{L})$.

Aplikasi limbah cair pabrik kelapa sawit (LCPKS) secara nyata dapat memperbaiki kesuburan tanah, terutama sifat kimia tanah; seperti hasil penelitian Ermadani dan Arsyad (2007) dimana aplikasi limbah cair pabrik kelapa sawit (LCPKS) dapat memperbaiki beberapa saifat kimia tanah, yaitu menaikkan $\mathrm{pH}, \mathrm{C}$-organik, N-total, Ptersedia, KTK, K-dd, Ca-dd, dan peningkatan Mg-dd. 
Muhammad Rio Purnomo, Ellen Lumisar Panggabean \& Siti Mardiana, Respon Pemberian Campuran Kompos Baglog Dengan Pupuk Kandang Sapi dan Pupuk Organik Cair (POC) Limbah Cair Pabrik Kelapa Sawit Terhadap Pertumbuhan dan Produksi Tanaman Kacang Panjang (Vigna sinensis L.)

\section{METODE PENELITIAN}

\section{Rancangan Penelitian}

Penelitian ini dilakukan dengan menggunakan metode Rancangan Acak Kelompok (RAK) Faktorial yang terdiri dari dua faktor perlakuan, yaitu :

1. Pupuk kompos campuran baglog dengan pupuk kandang sapi yang terdiri dari

4 taraf perlakuan yaitu :

B0 = Pupuk kandang sapi $1 \mathrm{~kg} /$ plot

$\mathrm{B} 1=($ Kompos baglog 2,8 $\mathrm{kg}+$ pupuk kandang sapi $1 \mathrm{~kg}) /$ plot

$\mathrm{B} 2=($ Kompos baglog 3,2 kg + pupuk kandang sapi $1 \mathrm{~kg}) /$ plot

$\mathrm{B} 3=($ Kompos baglog 3,6 kg + pupuk kandang sapi $1 \mathrm{~kg}) /$ plot

2. Pupuk organik Limbah cair pabrik kelapa sawit yang terdiri dari 4 taraf perlakuan yaitu :

$\mathrm{K} 0=$ Tanpa perlakuan

$\mathrm{K} 1$ = Limbah cair $50 \mathrm{ml} / \mathrm{L} \mathrm{K2}=$ Limbah cair $75 \mathrm{ml} / \mathrm{L} \mathrm{K3} \mathrm{=} \mathrm{Limbah} \mathrm{cair} 100 \mathrm{ml} / \mathrm{L}$ Pembuatan Kompos Limbah Baglog dan POC limbah Kelapa Sawit

Dalam pembuatan pupuk kompos baglog langkah pertama yaitu disiapkan alat dan bahan, adapun alat yang digunakan adalah cangkul, terpal, ember, gayung. Sedangkan bahan yang akan digunakan yaitu limbah baglog sebanyak $100 \mathrm{~kg}$, EM-4 (effective microorganisme) 1 liter, molase $500 \mathrm{ml}$, air 25 liter atau secukupnya. Limbah baglog ini diambil di daerah Medan, Jln. Benteng Hilir Ujung Lau Dendang No 19. Proses pembuatan kompos baglog sesuaidengan prosedur yang didiskripsikan (Rubiayah, 2012).

Proses pembuatan limbah cair kelapa sawit (LCKS) menjadi pupuk cair kelapa sawit dibutuhkan beberapa bahan, di antaranya: 1 kg Riyansidec, 250 gr Molasse dan limbah cari pabrik kelapa sawit yang diambil di Desa Bandar Meriah, Kecamatan Bangun Purba, Kabupaten Deli Serdang tepatnya di PT. Tales Inti Sawit (TIS). Sedangkan peralatan yang dibutuhkan, antara lain: drum air, mesin pengaduk (sanyo), ember plastik, alat pengukur pH dan kayu pengaduk. Prosedur kerja dalam pembuatan pupuk cair limbah kelapa sawit yaitu dengan memasukkan 1 kg Riyansidec, 250 gr molasses, 10 Liter air ke dalam drum, dan diaduk selama 1 jam, kemudian dimasukan 100 liter limbah cair kelapa sawit, lalu aduk dengan menggunakan water pump (mesin sanyo) selama 2-3 jam. Sebelum dilakukan treatment dianalisis pH, BOD dan COD Pada LCKS. Setelah 7 hari LCKS di ukur kembali pH, BOD dan COD. Bila BOD dan COD di bawah 5000 ppm dan pH 6-7, maka LCKS yang sudah menjadi pupuk cair kelapa sawit (PCKS) siap diaplikasikan pada tananam kacang panjang sesuai dengan masing- masing perlakuan (Ikmal, 2016 ). Pupuk organik cair limbah cair pabrik kelapa sawit yang sudah matang (yang telah mengalami fermentasi selama satu minggu) maka dilakukan analisa kandungan haranya ( N, P, K, Ca, Mg).

Persiapan Lahan, Aplikasi Perlakuan dan Pengamatan

Pengolahan tanah dilakukan setelah dibersihkan terlebih dahulu rumput- rumput yang ada di areal pertanian. Setelah keadaan lahan benar-benar bersih maka dilakukan pengolahan tanah. Pengolahan tanah dilakukan dua kali yaitu pengolahan pertama dengan mencangkul tanah sedalam 20 - $30 \mathrm{~cm}$ kemudian tanah dibiarkan selama 
seminggu. Pengolahan kedua dengan menghancurkan gumpalan-gumpalan tanah yang besar, agar diperoleh tanah yang gembur.

Pemberian pupuk kompos campuran baglog dengan pupuk kandang sapi diaplikasikan pada saat satu minggu sebelum tanam di masing-masing plot sesuai perlakuan dengan satu kali aplikasi saja. Sebelum diaplikasikan kompos baglog yang sudah jadi di campurkan dengan pupuk kandang sapi dan diaduk sampai benar-benar tercampur atau tercampur secara merata, kemudian di aplikasikan dengan cara disebar di plot secara merata. Pemberian pupuk organik cair limbah cair pabrik kelapa di aplikasikan pada saat 2 minggu setelah tanam dengan interval satu minggu sekali dan berakhir pada saat 5 minggu setelah tanam. Pengaplikasian pupuk organik cair limbah cair pabrik kelapa sawit dilakukan dengan cara di semprotkan pada daun tanman kacang panjang pada setiap plot sesuai dengan perlakuan dan kebutuhan pertumbuhan tanaman.

Penmeliharaan dilakukan secara teknis disertai dengan pengamatan. Adapun data yang diamati meliputi diameter batang, umur Bungan, jumlah poling persampel dan perplot, serta parameter prodksi lainnya. Kemudian dianalisis dengan statistika RAK dua Faktor

\section{HASIL DAN PEMBAHASAN} Diamete Batang (Cm)

Rangkuman sidik ragam pengaruh campuran kompos baglog dengan pupuk kandang sapi dan poc limbah cair kelapa sawit terhadap diameter batang dapat dilihat pada Tabel 1 .

Table 1. Rangkuman Sidik Ragam Pengaruh Campuran Kompos Baglog dengan Pupuk Kandang Sapi dan POC Limbah Cair Kelapa Sawit Terhadap Diameter Batang

\begin{tabular}{ccccccc}
\hline \multirow{2}{*}{ SK } & \multicolumn{3}{c}{ Diameter Batang } & \multicolumn{2}{c}{$\mathrm{F}_{\text {Tabel }}$} \\
\cline { 2 - 7 } & $2 \mathrm{MST}$ & $3 \mathrm{MST}$ & $4 \mathrm{MST}$ & $5 \mathrm{MST}$ & $\mathrm{F}_{0.05}$ & $\mathrm{~F}_{0.01}$ \\
\hline $\mathrm{B}$ & $0.66 \mathrm{tn}$ & $1.59 \mathrm{tn}$ & $1.50 \mathrm{tn}$ & $3.00 \mathrm{tn}$ & 3.29 & 5.42 \\
$\mathrm{~K}$ & $0.11 \mathrm{tn}$ & $1.65 \mathrm{tn}$ & $3.26 \mathrm{tn}$ & $5.02^{*}$ & 3.29 & 5.42 \\
$\mathrm{~B} / \mathrm{K}$ & $0.84 \mathrm{tn}$ & $2.52 \mathrm{tn}$ & $1.15 \mathrm{tn}$ & $1.55 \mathrm{tn}$ & 2.59 & 3.89 \\
\hline
\end{tabular}

Keterangan $: \operatorname{tn}=$ tidak nyata; ${ }^{*}=$ nyata.

Dari Tabel 1 dapat dilihat bahwa pemberian POC limbah cair kelapa sawit berpengaruh nyata pada umur 5 MST, tetapi berpengaruh tidak nyata pada umur $2-4$ MST. Sedangkan pemberian campuran kompos baglog dengan pupuk kandang sapi dan kombinasi kedua faktor perlakuan berpengaruh tidak nyata terhadap diameter batang sejak umur 2 - 5 MST.

Uji beda rataan faktor pemberian POC limbah cair kelapa sawit dan pengaruhnya terhadap diameter batang umur 5 MST dapat dilihat pada Tabel 2.

Table 2. Beda Rataan Pengaruh POC Limbah Cair Kelapa Sawit Terhadap Diameter Batang Umur 5 MST 
Muhammad Rio Purnomo, Ellen Lumisar Panggabean \& Siti Mardiana, Respon Pemberian Campuran Kompos Baglog Dengan Pupuk Kandang Sapi dan Pupuk Organik Cair (POC) Limbah Cair Pabrik Kelapa Sawit Terhadap Pertumbuhan dan Produksi Tanaman Kacang Panjang (Vigna sinensis L.)

\begin{tabular}{cccc}
\hline \multirow{2}{*}{ Perlakuan } & \multirow{2}{*}{ Rataan } & \multicolumn{2}{c}{ Notasi } \\
\cline { 2 - 4 } & & $\alpha_{0.05}$ & $\alpha_{0.01}$ \\
$\mathrm{~K}_{0}$ & 0.61 & $\mathrm{~b}$ & $\mathrm{~A}$ \\
$\mathrm{~K}_{1}$ & 0.62 & $\mathrm{ab}$ & $\mathrm{A}$ \\
$\mathrm{K}_{2}$ & 0.64 & $\mathrm{ab}$ & $\mathrm{A}$ \\
$\mathrm{K}_{3}$ & 0.65 & $\mathrm{a}$ & $\mathrm{A}$ \\
\hline Keterangan : & Angka-angka yang diikuti notasi huruf yang berbeda pada satu kolom menunjukkan \\
& berbeda nyata pada taraf uji 0,05 (huruf kecil) dan berbeda sangat nyata pada taraf \\
& uji 0,01 (huruf besar).
\end{tabular}

Pengaruh yang nyata dari pemberian POC limbah cair kelapa sawit erat kaitannya dengan kandungan hara yang terdapat dalam POC limbah cair kelapa sawit. Hal ini sesuai dengan hasil analisa limbah cair kelapa sawit yang dilakukan di Laboratorium PT. Socfin Indonesia, dimana diperoleh: C-organik 0,12\%, K 0,67\%, N 0,58\%, P 0,90\% dan C/N 10,9 yang berarti POC limbah cair kelapa sawit ini sudah layak digunakan untuk mendukung pertumbuhan dan perkembangan tanaman. Hal ini sesuai dengan pendapat Hadisuwito (2012) dalam Hanisar dan Bahrum (2015) yang mengatakan bahwa pupuk organik cair umumnya tidak merusak tanah dan tanaman meskipun sudah digunakan sesering mungkin. Selain itu, pupuk ini juga memiliki bahan pengikat sehingga larutan pupuk yang diberikan ke permukaan daun bisa langsung dimanfaatkan oleh tanaman.

Menurut Hidayati (2009), pupuk N, P dan K sangat dibutuhkan untuk pertumbuhan tanaman terutama dalam merangsang pertumbuhan tinggi tanaman dan pembesaran diameter batang. Selanjutnya Efendi dan Suwardi (2010) menjelaskan bahwa batang berperan menopang tegaknya tanaman, semakin besar diameter batang berarti tanaman akan semakin kokoh. Sedangkan menurut Widiyastiningsih, et al. (2012), pertambahan ukuran tubuh tanaman diakibatkan pertambahan jaringan sel yang dihasilkan oleh pertambahan ukuran sel.

Umur Berbunga (hari)

pemberian campuran kompos baglog dengan pupuk kandang sapi berpengaruh nyata, pemberian POC limbah cair kelapa sawit berpengaruh sangat nyata, tetapi kombinasi kedua faktor perlakuan berpengaruh tidak nyata terhadap umur berbunga. Uji beda rataan faktor pemberian campuran kompos baglog dengan pupuk kandang sapi dan POC limbah cair kelapa sawit dan pengaruhnya terhadap umur berbunga dapat dilihat pada Tabel 3.

Table 3. Beda Rataan Pengaruh Pemberian Campuran Baglog dengan Pupuk Kandang Sapi dan POC Limbah Cair Kelapa Sawit Terhadap Umur Berbunga 


\begin{tabular}{cccc}
\hline \multirow{2}{*}{ Perlakuan } & \multirow{2}{*}{ Rataan } & \multicolumn{2}{c}{ Notasi } \\
\cline { 3 - 4 } & & $\alpha_{0.05}$ & $\alpha_{0.01}$ \\
\hline $\mathrm{B}_{0}$ & 34.63 & $\mathrm{a}$ & $\mathrm{A}$ \\
$\mathrm{B}_{1}$ & 34.25 & $\mathrm{ab}$ & $\mathrm{A}$ \\
$\mathrm{B}_{2}$ & 33.88 & $\mathrm{ab}$ & $\mathrm{A}$ \\
$\mathrm{B}_{3}$ & 33.63 & $\mathrm{~b}$ & $\mathrm{~A}$ \\
\hline $\mathrm{K}_{0}$ & 35.00 & $\mathrm{a}$ & $\mathrm{A}$ \\
$\mathrm{K}_{1}$ & 34.00 & $\mathrm{~b}$ & $\mathrm{AB}$ \\
$\mathrm{K}_{2}$ & 33.75 & $\mathrm{~b}$ & $\mathrm{~B}$ \\
$\mathrm{~K}_{3}$ & 33.63 & $\mathrm{~b}$ & $\mathrm{~B}$ \\
\hline Keterangan : Angka-angka yang diikuti notasi huruf yang berbeda pada satu kolom menunjukkan \\
berbeda nyata pada taraf uji 0,05 (huruf kecil) dan berbeda sangat nyata pada taraf \\
uji 0,01 (huruf besar).
\end{tabular}

Dari Tabel 3 dapat dijelaskan bahwa pada faktor pemberian campuran kompos baglog dengan pupuk kandang sapi diperoleh bahwa perlakuan B0 berbeda nyata terhadap B3, tetapi berbeda tidak nyata terhadap B1 dan B2. Sedangkan pada faktor pemberian POC limbah cair kelapa sawit diperoleh bahwa perlakuan K0 berbeda sangat nyata terhadap K2 dan K3 dan berbeda nyata terhadap perlakuan K1. Tetapi perlakuan K1 berbeda tidak nyata terhadap K2 dan K3. Hal ini sesuai dengan pendapat Arnando, et al. (2013) yang mengatakan bahwa perbedaan umur berbunga pada tiap tanaman dapat terjadi akibat pengaruh jumlah unsur hara yang diserap oleh tanaman. Hubungan antara pemberian kompos campuran baglog dengan pupuk kandang sapi terhadap umur berbunga dapat dilihat pada Gambar 1.

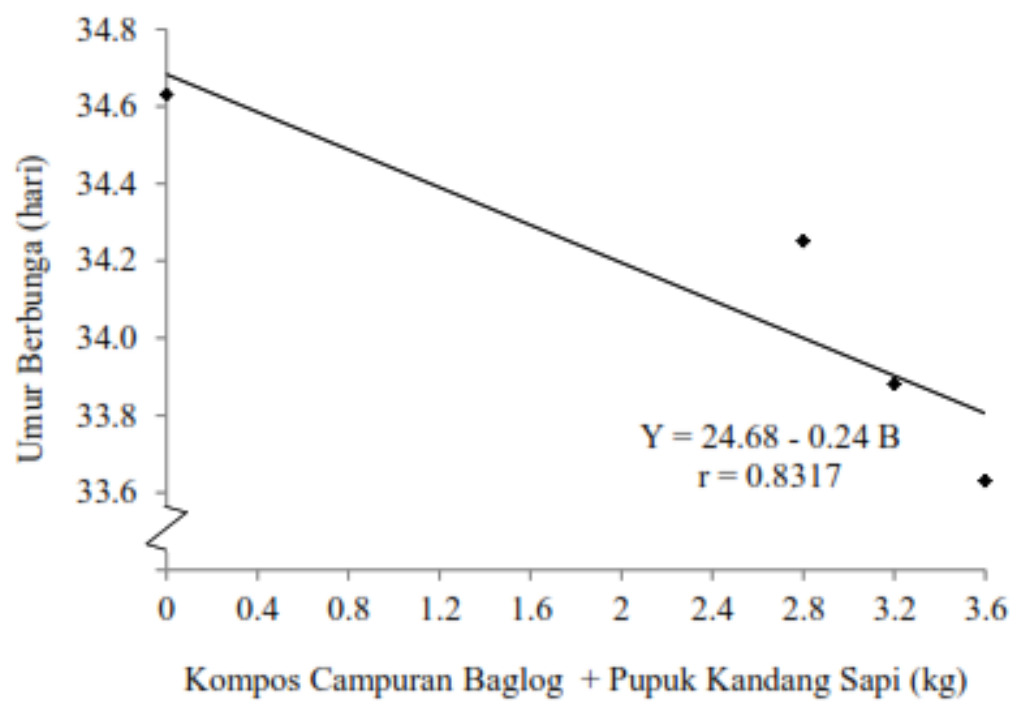

Gambar 1. Kurva Respon Perubahan Umur Berbunga (hari) Sebagai Akibat Pemberian Campuran Kompos Baglog dengan Pupuk Kandang Sapi

bentuk kurva respon hubungan antara pemberian kompos campuran baglog dengan pupuk kandang sapi dengan umur berbunga adalah linier negatif, dengan persamaan : $\mathrm{Y}=24,68-0,24$ B. Nilai koefisien regresi $(r=0,8317)$ menjelaskan bahwa pemberian kompos campuran baglog dengan pupuk kandang sapi memberikan pengaruh sebesar $83,17 \%$ terhadap perubahan umur berbunga. 
Muhammad Rio Purnomo, Ellen Lumisar Panggabean \& Siti Mardiana, Respon Pemberian Campuran Kompos Baglog Dengan Pupuk Kandang Sapi dan Pupuk Organik Cair (POC) Limbah Cair Pabrik Kelapa Sawit Terhadap Pertumbuhan dan Produksi Tanaman Kacang Panjang (Vigna sinensis L.)

Pemberian campuran kompos baglog dengan pupuk kandang sapi, pemberian POC limbah cair kelapa sawit dan kombinasi antara kedua faktor perlakuan berpengaruh tidak nyata terhadap jumlah polong per tanaman sampel. Tidak nyatanya pemberian campuran kompos baglog dengan pupuk kandang sapi dan pemberian POC limbah cair kelapa sawit pada parameter jumlah polong/tanaman sampel disebabkan karena adanya serangan penyakit pada tanaman selama penelitian berlangsung, sehingga ada beberapa tanaman sampel yang pertumbuhannya lambat dan pada akhirnya produksinya pun menjadi berkurang. Penyakit yang terserang pada tanaman kacang panjang disebabkan oleh virus, penyebaran atau pembawa virus ini dibantu hama kutu daun Aphis craccivora Koch yang memiliki ciri-ciri berukuran kecil, lunak, dan berwarna hitam. Sebagian besar jenis serangga ini tidak bersayap, tetapi bila populasi meningkat, sebagian serangga dewasanya membentuk sayap bening. Tanaman yang terserang Aphis craccivora akan menjadi kerdil, daun mengeriting, muncul bercak-bercak, dan warna daun menguning, diikuti kelayuan dan kematian serta dapat mempengaruhi kualitas dan hasil tanaman kacang-kacangan. Hama ini juga bertindak sebagai vektor (serangga penular) berbagai penyakit virus kacang- kacangan (Soybean Mosaic Ynts, Soybean Yellow Mosaic Virus, Bean Yellow Mosaic Virus, Soybean Dwarf Yrus, Peanut Stripe Virus, dan lain-lain). (Kalshoven, 1981).

\section{Panjang Polong/Tanaman Sampel (cm)}

pemberian campuran kompos baglog dengan pupuk kandang sapi berpengaruh tidak nyata, pemberian POC faktor perlakuan berpengaruh nyata terhadap panjang polong per tanaman sampel. Pengaruh yang tidak nyata dari pemberian campuran kompos baglog dengan pupuk kandang sapi disebabkan karena unsur hara yang tersedia pada campuran kompos ini tidak lagi mencukupi untuk fase generatif tanaman, karena sudah diserap untuk pertumbuhan diameter batang dan panjang polong. Dalam hal ini baglog yang digunakan merupakan bekas budidaya jamur, sehingga kandungan hara yang terdapat di dalamnya pun sudah dipergunakan untuk pertumbuhan dan produksi jamur. Sementara penambahan pupuk kandang sapi pun masih sangat rendah, yakni 0,5 $\mathrm{kg} / \mathrm{m} 2$ atau setara dengan 5 ton/ha.

Beda rataan pengaruh Pemberian Campuran Baglog dengan Pupuk Kandang Sapi, POC Limbah Cair Kelapa Sawit dan Kombinasinya Terhadap Panjang Polong/Tanaman Sampel disajikan pada table 4 .

Table 4. Beda Rataan Pengaruh Pemberian Campuran Baglog dengan Pupuk Kandang Sapi, POC Limbah Cair Kelapa Sawit dan Kombinasinya Terhadap Panjang Polong/Tanaman Sampel 
Jurnal Ilmiah Pertanian (JIPERTA), 1(1) 2020: 33-43,

\begin{tabular}{cccc}
\hline \multirow{2}{*}{ Perlakuan } & \multirow{2}{*}{ Rataan } & \multicolumn{2}{c}{ Notasi } \\
\cline { 3 - 4 } & & $\alpha_{0.05}$ & $\alpha_{0.01}$ \\
\hline $\mathrm{K}_{0}$ & 62.98 & $\mathrm{~b}$ & $\mathrm{~B}$ \\
$\mathrm{~K}_{1}$ & 63.85 & $\mathrm{~b}$ & $\mathrm{AB}$ \\
$\mathrm{K}_{2}$ & 66.74 & $\mathrm{a}$ & $\mathrm{A}$ \\
$\mathrm{K}_{3}$ & 66.93 & $\mathrm{a}$ & $\mathrm{A}$ \\
\hline $\mathrm{B}_{0} \mathrm{~K}_{0}$ & 58.78 & $\mathrm{e}$ & $\mathrm{A}$ \\
$\mathrm{B}_{0} \mathrm{~K}_{1}$ & 63.34 & $\mathrm{~cd}$ & $\mathrm{~A}$ \\
$\mathrm{~B}_{0} \mathrm{~K}_{2}$ & 68.23 & $\mathrm{ab}$ & $\mathrm{A}$ \\
$\mathrm{B}_{0} \mathrm{~K}_{3}$ & 70.11 & $\mathrm{a}$ & $\mathrm{A}$ \\
$\mathrm{B}_{1} \mathrm{~K}_{0}$ & 66.48 & $\mathrm{abcd}$ & $\mathrm{A}$ \\
$\mathrm{B}_{1} \mathrm{~K}_{1}$ & 63.27 & $\mathrm{~cd}$ & $\mathrm{~A}$ \\
$\mathrm{~B}_{1} \mathrm{~K}_{2}$ & 66.31 & $\mathrm{abcd}$ & $\mathrm{A}$ \\
$\mathrm{B}_{1} \mathrm{~K}_{3}$ & 66.85 & $\mathrm{abc}$ & $\mathrm{A}$ \\
$\mathrm{B}_{2} \mathrm{~K}_{0}$ & 62.48 & $\mathrm{de}$ & $\mathrm{A}$ \\
$\mathrm{B}_{2} \mathrm{~K}_{1}$ & 64.56 & bcd & $\mathrm{A}$ \\
$\mathrm{B}_{2} \mathrm{~K}_{2}$ & 64.31 & bcd & $\mathrm{A}$ \\
$\mathrm{B}_{2} \mathrm{~K}_{3}$ & 66.70 & abcd & $\mathrm{A}$ \\
$\mathrm{B}_{3} \mathrm{~K}_{0}$ & 64.20 & bcd & $\mathrm{A}$ \\
$\mathrm{B}_{3} \mathrm{~K}_{1}$ & 64.22 & bcd & $\mathrm{A}$ \\
$\mathrm{B}_{3} \mathrm{~K}_{2}$ & 68.14 & ab & $\mathrm{A}$ \\
$\mathrm{B}_{3} \mathrm{~K}_{3}$ & 64.07 & bcd & $\mathrm{A}$ \\
\hline berbeda nyata pada taraf uji & 0,05 (huruf kecil) dan berbeda sangat nyata pada taraf \\
uji 0,01 (huruf besar). & & &
\end{tabular}

Dari Tabel 4 dapat dijelaskan bahwa pada faktor pemberian POC limbah cair kelapa sawit diperoleh perlakuan K3 berbeda sangat nyata terhadap K0, berbeda nyata terhadap K1, tetapi berbeda tidak nyata terhadap perlakuan $\mathrm{K} 2$. Sedangkan pada kombinasi kedua faktor perlakuan diperoleh bahwa perlakuan B0K3 berbeda nyata terhadap B0K0, B0K1, B1K1, B2K0, B2K1, B2K2, B3K0, B3K1 dan B3K3, tetapi berbeda tidak nyata terhadap B0K2, B1K0, B1K2, B1K3, B2K3 dan B3K2.

Pengaruh yang nyata dari pemberian POC limbah cair kelapa sawit ini erat kaitannya dengan unsur hara yang terkandung di dalam limbah cair kelapa sawit, dimana limbah cair kelapa sawit mengandung unsur nitrogen, posfor, kalium yang tergolong tinggi. Hal ini sesuai dengan analisis POC limbah cair kelapa sawit yang dilakukan di Laboratorium PT. Socfin Indonesia menunjukkan bahwa kandungan di dalamnya yaitu C-organik 0,12, K 0,67\%, N 0,58\%, P 0,90\% dan C/N 10,9. Unsur N diserap oleh tanaman dalam bentuk NO3-yang terdapat dalam larutan tanah. Unsur ini secara langsung berperan dalam pembentukan protein, memacu pertumbuhan tanaman secara umum terutama pada fase vegetatif, berperan dalam pembetukan klorofil, asam amino, lemak enzim, dan persenyawaan lain (Pambudi, 2013 dalam Wahyudi, 2018). Unsur K dalam tanaman tidak menjadi komponen terstruktur dalam senyawa organik, namun mutlak dibutuhkan untuk proses pertumbuhan dan hasil tanaman. Unsur $\mathrm{K}$ merupakan pengaktif dari sejumlah besar enzim penting untuk fotosintesis dan respirasi (Salisbury dan Ross, 1995 dalam Wahyudi, 2018).

Unsur N diserap oleh tanaman dalam bentuk NO3- yang terdapat dalam larutan tanah. Unsur ini secara langsung berperan dalam pembentukan protein, memacu pertumbuhan tanaman secara umum terutama pada fase vegetatif, berperan dalam pembetukan klorofil, asam 
Muhammad Rio Purnomo, Ellen Lumisar Panggabean \& Siti Mardiana, Respon Pemberian Campuran Kompos Baglog Dengan Pupuk Kandang Sapi dan Pupuk Organik Cair (POC) Limbah Cair Pabrik Kelapa Sawit Terhadap Pertumbuhan dan Produksi Tanaman Kacang Panjang (Vigna sinensis L.)

amino, lemak enzim, dan persenyawaan lain (Pambudi, 2013 dalam Wahyudi, 2018). Unsur K dalam tanaman tidak menjadi komponen terstruktur dalam senyawa organik, namun mutlak dibutuhkan untuk proses pertumbuhan dan hasil tanaman. Unsur K merupakan pengaktif dari sejumlah besar enzim penting untuk fotosintesis dan respirasi (Salisbury dan Ross, 1995 dalam Wahyudi, 2018).

\section{Berat Polong/Tanaman Sampel (g)}

daftar sidik ragam menunjukkan bahwa pemberian POC limbah cair kelapa sawit berpengaruh nyata, sedangkan pemberian campuran kompos baglog dengan pupuk kandang sapi dan kombinasi antara kedua faktor perlakuan berpengaruh tidak nyata terhadap berat polong per tanaman sampel.

Pengaruh yang tidak nyata dari pemberian campuran kompos baglog dengan pupuk kandang sapi disebabkan karena unsur hara yang tersedia pada campuran kompos ini tidak lagi mencukupi untuk fase generatif tanaman, karena sudah diserap untuk pertumbuhan diameter batang dan panjang polong. Dalam hal ini baglog yang digunakan merupakan bekas budidaya jamur, sehingga kandungan hara yang terdapat di dalamnya pun sudah dipergunakan untuk pertumbuhan dan produksi jamur. Sementara penambahan pupuk kandang sapi pun masih sangat rendah, yakni 0,5 kg/m2 atau setara dengan 5 ton/ha. Dari hasil penelitian Neltriana (2015) diperoleh bahwa pemberian pupuk kandang sapi sebanyak 15 ton/ha menghasilkan pertumbuhan dan produksi yang terbaik pada tanaman ubi jalar. Selanjutnya Tufaila, dkk. (2013) melaporkan bahwa pemberian bokashi kotoran sapi dengan dosis 5-7,5 ton/ha memberikan pengaruh yang lebih baik terhadap pertumbuhan dan produksi padi sawah varietas Konawe. Yuliana, dkk. (2013) juga melaporkan bahwa pemberian pupuk kandang sapi sebanyak 5 ton/ha menghasilkan pertumbuhan dan produksi jahe yang tertinggi.

\section{SIMPULAN}

Berdasarkan penelitian yang telah dilaksanakan dapat disimpulkan bahwa pemberian campuran kompos baglog dengan pupuk kandang sapi berpengaruh tidak nyata terhadap diameter batang, jumlah polong per tanaman sampel, panjang polong per tanaman sampel, berat polong per tanaman sampel dan produksi per plot, tetapi berpengaruh nyata terhadap umur berbunga. Pemberian POC limbah cair kelapa sawit berpengaruh nyata terhaap diameter batang umur 5 MST, umur berbunga, jumlah polong per tanaman sampel, panjang polong per tanaman sampel, berat polong per tanaman sampel dan produksi per plot. Kombinasi kedua faktor perlakuan berpengaruh nyata terhadap panjang polong per tanaman sampel dan produksi per plot, tetapi berpengaruh tidak nyata terhadap parameter lainnya.

\section{DAFTAR PUSTAKA}

Arnanto D, Basuki N, \& Respatijarti R. (2013). Uji Toleransi Salinitas Terhadap Sepuluh Genotip F1 Tomat (Solanum Lycopersicum L.). Jurnal Produksi Tanaman, 1(5).

Chazali S, \& Pratiwi PS. (2009). Usaha Jamur Tiram Skala Rumah Tangga: Niaga Swadaya.

Ermadani E. (2011). Pengaruh aplikasi limbah cair pabrik kelapa sawit terhadap hasil kedelai dan perubahan sifat kimia tanah Ultisol. Indonesian Journal of Agronomy, 39(3), 7757.

Hanisar W. (2015). Pengaruh Pemberian Pupuk Organik Cair terhadap Pertumbuhan dan Hasil Beberapa Varietas Kacang Hijau (Vigna radiata L.). Universitas PGRI Yogyakarta. 
Haryanto E, Suhartini T, \& Rahayu E. (2007). Budidaya kacang panjang. Penebar Swadaya. Jakarta.

Ideriah T], Adiukwu PU, Stainley H, \& Briggs A. (2007). Impact of palm oil (Elaeis guineensis Jacq; Banga) mill effluent on water quality of receiving Oloya Lake in Niger Delta, Nigeria. Res. J. Appl. Sci, 2, 842845.

Kalshoven LGE. (1950). Pests of crops in Indonesia. Pests of crops in Indonesia.

Nubriama, R., Pane, E., \& Hutapea, S. (2019). pengaruh pemberian pupuk organik cair kandang kelinci dan kompos limbah baglog pada pertumbuhan bibit Kakao (theobroma cacao l.) Di polibeg. Jurnal Ilmiah Pertanian ( JIPERTA), 1(2), 143-152.

PEMBALIKAN W. (2014). PEMBUATAN KOMPOS LIMBAH LOG JAMUR TIRAM: KAJIAN KONSENTRASI KOTORAN KAMBING DAN EM4 SERTA. Jurnal Teknologi Pertanian, 15(1), 59-66.

Pranata AS. (2010). Meningkatkan hasil panen dengan pupuk organik: AgroMedia.

Rahmah, F., Arifin, M., \& Anam, K. (2019). PROSES ADOPSI INOVASI PUPUK CAIR ORGANIK MIKRO ORGANISME LOKAL (MOL) DI KELURAHAN GEBANG KECAMATAN PATRANG KABUPATEN JEMBER. JURNAL AGRICA, 12(1), 1-6. doi:https://doi.org/10.31289/agrica.v12i1.2016

Sahputra, H., Suswati, S., \& Gusmeizal, G. (2019). Efektivitas aplikasi kompos kulit kopi dan Fungi mikoriza arbuskular terhadap produktivitas jagung manis. Jurnal Ilmiah Pertanian ( JIPERTA), 1(2), 102-112.

Setyorini D. (2005). Pupuk organik tingkatkan produksi pertanian. Warta Penelitian dan Pengembangan Pertanian, 27(6), 13-15.

Simajuntak, M., Hasibuan, S., \& Maimunah, M. (2019). Efektivitas Penggunaan Bokashi Blotong Tebu dan Pemberian Pupuk Organik Cair Kulit Nanas Terhadap Produktifitas Tanaman Kecipir (Psophocarpus tetragonolobus L.). Jurnal Ilmiah Pertanian ( JIPERTA), 1(2), 133-142.

Sulaeman D. (2011). Efek Kompos Limbah Baglog Jamur Tiram Putih (Pleurotus ostreanus Jacquin) terhadap Sifat Fisik Tanah serta Tumbuhan Bibit Markisa Kuning (Passiflora edulis var. Flavicarpa Degner). Institut Pertanian Bogor. Bogor.

Sunarjono HH. (2004). Bertanam 36 jenis sayur: Penebar Swadaya Grup.

Wahyudi W. (2017) Pengaruh pemberian limbah cair pabrik kelapa sawit terhadap pertumbuhan dan hasil kedelai edamame (glycine max (l.) Merril) pada tanah ultisol. Agroekoteknologi.

Zahara I. (2014). Pengaruh Pengadukan terhadap Produksi Biogas pada Proses Metanogenesis Berbahan Baku Limbah Cair Kelapa Sawit. Skripsi. Jurusan Teknik Kimia, Universitas Sumatera Utara, Sumatera Utara. 